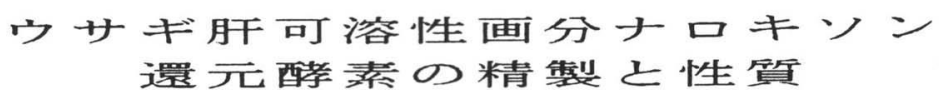

○山野 茂, 一瀬文雄, 土岐 智 福岡大学薬学部衛生化学教室

\title{
PURIFICATION AND CHARACTERIZATION OF NALOXONE REDUCTASES FROM CYTOSOL OF RABBIT LIVER
}

\author{
Shigeru YAMANO, Fumio ICHINOSE and Satoshi TOKI \\ Faculty of Pharmaceutical Sciences, Fukuoka University, \\ Fukuoka $814-80$
}

【目的】麻薬拮抗薬であるナロキソンは, 主に 3 位水酸基のグルクロン酸抱合反 応を受けて代謝される. その他に 6 位ヶトン基の還元および $\mathrm{N}$-脱アリル化反応を 受ける代謝経路がある. In vitro での 6 位ケトン基の還元反応については, 広範 囲の動物種で研究されており, 種々の哺乳動物や鳥類の肝可溶性画分は, NAD (P)H 依存性で $6 a$-および/あるいは $6 \beta$-ナロキソールの生成を触媒するナロキソン還元

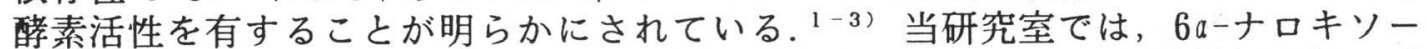
ルへの還元反応を触媒するナロキソン還元酵素を，モルモット肝可溶性画分から精 製し, この酵素がモルフィン 6 位水酸基の脱水素反応に㗢くモルフィン 6-脱水素 酵素 ${ }^{4)}$ と同一酵素であることを明らかにした. ${ }^{5}$ ) モルモット以外の動物種でナロキ ソン還元酵素は精製されていないが, ウサギ肝可溶性画分には, 等電点電気泳動の 結果から少なくとも 3 種の酵素の存在が考えられている.6) 本研究では, ウサギ 肝可溶性画分の酵素の精製を試み, 性質についても検討した.

【方法】1. 酵素の精製：ウサギ肝可溶性画分を硫安分画後, Fig. 1 に示している 種々のクロマトグラフィーを行うことにより 4 種の酵素を精製した. 2. 酵素活性

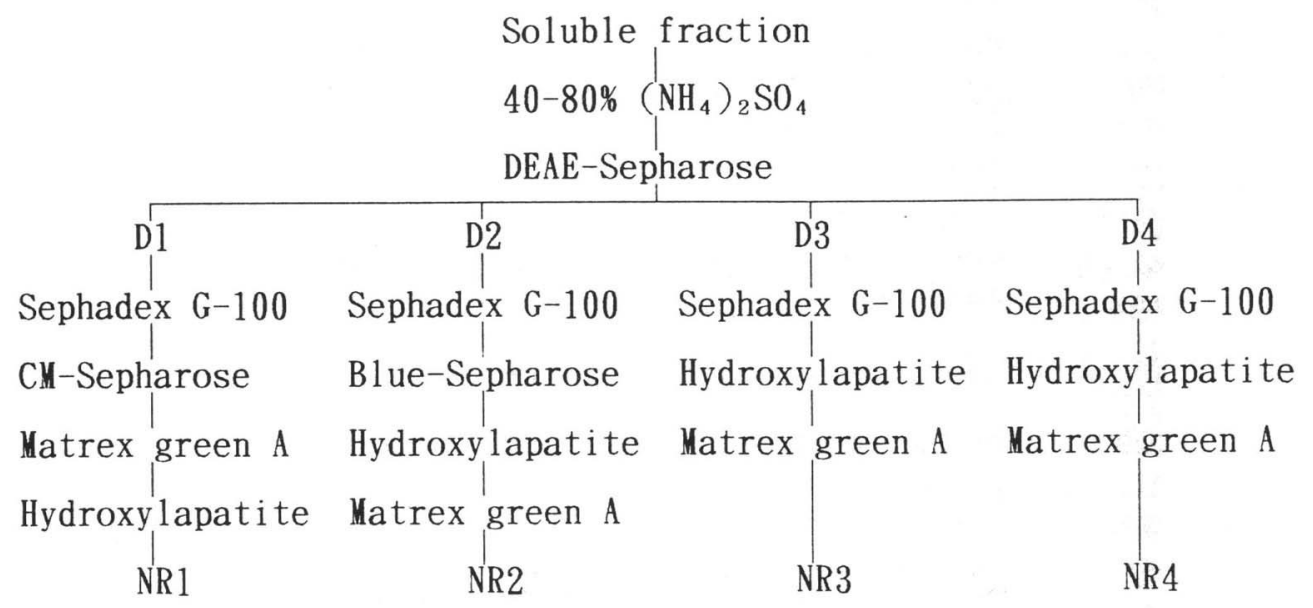

Fig. 1. Flow chart of purification procedure of naloxone reductases. 
の測定：反応液は, 0.1 I Na phosphate buffer ( $\mathrm{pH} 7.4), 0.167 \mathrm{~m}$ NADPH, $1 \mathrm{~m}$ I ナロキソンおよび酵素より成り, 全量を $1.5 \mathrm{ml}$ とした。活性は NADPH の消失に 基ずく $340 \mathrm{~nm}$ の吸光度の減少により求めた３. 反応生成物の同定：反応液は, 飽和 $\mathrm{NaHCO}_{3}$ 水溶液で $\mathrm{pH}$ を 8.5 に調整した後, 酢酸エチルで抽出し, この抽出 液について TLC を行った。展開溶媒として $\mathrm{CHCl}_{3} /$ methanol $/ 28 \% \mathrm{NH}_{4} \mathrm{OH}(90: 10: 4$, by vol. ) を用い, 反応生成物の検出は, ヨウ化白金酸カリウム試液で行った。

【結果】1. 酵素の精製: 本酵素活性は, 硫安分画後の DEAE-Sepharose カラムク ロマトグラフィーの段階で, 未吸着部分 (D1) と $\mathrm{NaCl}$ 濃度 0.10 M (D2), 0.13 y (D3) および 0.20 （D4）付近に溶出する計 4 つのピークに分離した. D1，D2， D3 とD4 には，それぞれ硫安分画の活性の約 37\%，24\%，11\% および 30\% が認め られた。 D1，D2，D3 と D4 から，Fig.1 に示しているクロマトグラフィーを行う ことにより，4 種の酵素（NR1，NR2，NR3 および NR4）を, SDS-PAGE で単一バン ドを示す標品にまで精製した（Fig.2）. NR1，NR2，NR3 および NR4 の比活性は， それぞれ 31，38，87 および 118 mil1iunits/mg protein で, 可溶性画分からそ れぞれ約 42，53，121 および 164 倍精製されていた。なお，D2 では B1ueSepharose の段階で, また D3 では Matrex green A の段階で NR2 と NR3 以外の 弱い本酵素活性のピークが検出された。また，モルフィン 6-脱水素酵素活性は， DEAE-Sepharose カラムクロマトグラフィーにおいて D2 とほとんど同時に溶出し， Blue-Sepharose の段階でお互いに分離した。 2. 反応生成物の同定：可溶性画分 は 6a-体および 6 -体の両者を生成するが, Fig. 3 に示す TLC の結果から, 精製 酵素ではNR1 のみは 6a-体への，一方 NR2，NR3 および NR4 はいずれも6月-体へ の立体特異的な還元反応を触媒することが明らかになった．3. 分子量および等電 点: NR1, NR2, NR3 および NR4 の SDS-PAGE で求めた分子量は, それぞれ 37,000, 38,000，36,000 および 36,000であり，またゲルろ過で得た值も類似していたこ とから，4 者はお互いに分子量が近似する単量体であることが明らかになった (Table 1). NR1，NR2，NR3 および NR4 の等電点は，それぞれ 9.1，7.0,6.1 お よび 5.4 の值を示すことから(Table 1), NR1 は塩基性, NR2 は中性, NR3 と NR4 は弱酸性のタンパク質と考えられる。4. 至適 $\mathrm{pH}$, 補酵素要求性, $\mathrm{Km}$ 值および Vmax 值 : NR1 は pH 8.0の弱塩基性の条件下で最大の活性を与えたのに対し, NR2, NR3 と NR4 はいずれもpH 6 前後の弱酸性の条件で最大の活性を示した(Table 1). NADHを補酵素に用いた場合，NR1 とNR2 は，それぞれNADPH の場合の約 46\%と29\%

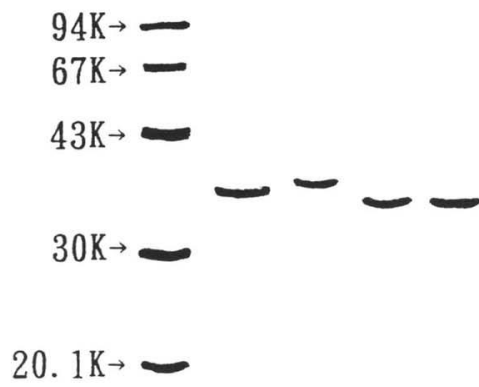

NR1 NR2 NR3 NR4

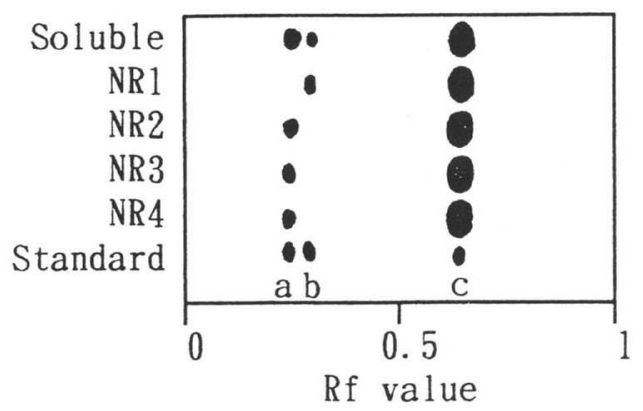

Fig. 3. TLC analys is of reaction product. a, 63-naloxol; b, 6analoxol; c, naloxone. 
Table 1. Property of naloxone reductases

\begin{tabular}{lcccc}
\hline & NR1 & NR2 & NR3 & NR4 \\
\hline Molecular weight & & & & \\
$\quad$ by SDS-PAGE & 37,000 & 38,000 & 36,000 & 36,000 \\
$\quad$ by ge1 filtration & 35,000 & 35,000 & 36,000 & 33,000 \\
Isoelectric point & 9.1 & 7.0 & 6.1 & 5.4 \\
Optimum pH & 8.0 & 5.5 & 6.2 & 6.1 \\
Km value & & & & \\
$\quad$ for naloxone (m.M) & 1.43 & 1.25 & 0.13 & 0.053 \\
$\quad$ for NADPH ( $\mu$ M) & 4.7 & 43.5 & 50.0 & 13.5 \\
Vmax value (mi11iunits/mg) & 67.6 & 50.6 & 91.9 & 120 \\
\hline
\end{tabular}

の活性を示したが，NR3 と NR4 はほとんど活性を示さなかった。ナロキソンに対 する Km 值は, NR4 が最低で (Table 1), 4 者の中で最も強い親和性を有している. NR1 とNR2 の Km 值は, NR3 や NR4 の値の 10-25 倍を示すことから (Table 1), 両者に比べて親和性は明らかに低いものと考えられる。Vmax 値を含めて考えると， NR4 が最も有効にナロキソンを基質として利用するものと思われる. 5 . 基質特異 性 : Table 2 に各種カルボニル化合物に対する 4 種の酵素の反応性を示している. ナロキソン類似化合物に対して, NR1 はモルフィノンに弱い活性（ナロキソンの約 19\%）を示したが，他の化合物にはほとんどあるいは全く活性を示さなかった．NR2， NR3 と NR4 は, ナルトレキソン, ジヒドロモルフィノンとモルフィノンにナロキ ソンと同程度かやや強い活性を示したが, 3 位水酸基が修飾されているオキシコド ン, ジヒドロコデイノン，コデイノンやエチルモルフィノンに対する反応性は極め て弱いものであった。他のカルボニル化合物に刘して，4 種の酵素ともグリセルア ルデヒド，p-ニトロベンズアルデヒド， $\mathrm{p}-$ ニトロアセトフェノン，フェナントレン キノンに目立って強い活性を示した。また，ステロイド類に対して，NR1 は主に

Table 2. Substrate specificity of naloxone reductases

\begin{tabular}{|c|c|c|c|c|c|}
\hline \multirow[t]{2}{*}{ Subst } & \multirow{2}{*}{$\begin{array}{l}\text { Concenträ- } \\
\text { tion }(\mathbf{m} \mathbf{H})\end{array}$} & \multicolumn{4}{|c|}{ Relative activity (\%) } \\
\hline & & NR1 & NR2 & NR3 & 7 \\
\hline Naloxone & 1 & 100 & 100 & 100 & \\
\hline Naltrexone & 1 & 5 & 93 & 143 & \\
\hline Oxycodone & 1 & 5 & 7 & 7 & \\
\hline Dihydromorphinone & 1 & 5 & 133 & 96 & \\
\hline Dihydrocodei i & 1 & 0 & 5 & 4 & \\
\hline Morphinone & 1 & 19 & 111 & 80 & \\
\hline Code i & 1 & 7 & 11 & 26 & \\
\hline ohinone & 1 & 0 & 9 & 0 & \\
\hline Gala & 100 & 8 & 17 & 3 & \\
\hline raldel & 10 & 448 & 156 & 324 & \\
\hline $\mathrm{p}-\mathrm{Ni}$ trobenzalde & 1 & 1117 & 192 & 346 & \\
\hline & 1 & 293 & 221 & 507 & \\
\hline he & 1 & 4000 & 614 & 529 & \\
\hline $5 a-$ Androstan-17 $\beta-$ ol-3-one & 0.1 & 21 & 492 & 128 & \\
\hline$\beta-$ Androstan $-17 \beta-0$ & 0.1 & 0 & 107 & 139 & \\
\hline $5 a-$ Androstan $-3 a-0$ & 0.1 & 207 & 176 & 335 & \\
\hline$\beta$-Androstan-3a-ol-17-one & 0.1 & 4 & 164 & 130 & \\
\hline
\end{tabular}


17 位の, NR2 と NR3 は 3 と 17 両部位の, NR4 は 17 位のオキソ基の還元反応 を触媒した，反応性は，酵素によってまたステロイドの A 環と B 環の配位の相異

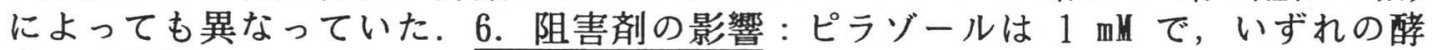
素にも影響を及ぼさなかった。バルビタールは 1 mI で, NR1 と NR2 を約 50\% 阻 害したが，NR3 とNR4 には影響を及ぼさなかった。これらに比べ，ケルセチンは 0.1 mI r゙， 4 種の酵素を強く阻害した。 SH 阻害剤の $\mathrm{p}$-クロル安息香酸は, NR1, NR3 と NR4 を強く阻害したが，NR2 には阻害効果を有していなかった。また，リ トコール酸は, 4 種の酵素の強力な阻害剤であることが判明した.

【結論・考察】今回ウサギ肝可溶性画分から精製した 4 種のナロキソン還元酵素 は, いずれも低分子量の単量体で, 補酵素として NADPH を主に利用し, ナロキソ ン 6 位ケトン基の立体特異的な還元反応を触媒した。ナロキソン類似化合物以外 にも，グリセルアルデヒド，芳香族アルデヒド・ケトン，キノンやオキソステロイ ドに強い活性を示し, 各種カルボニル化合物に反応性を示すことが明らかになった. また,ケルセチンは 4 種の酵素を強力に阻害した. 4 種の酵素間の物理化学的・酵 素化学的性質は類似していたが, 等電点, 至適 $\mathrm{pH}$, 補酵素要求性, 各種カルボ二 ル化合物に対する反応性や阻害片による影響などにいくらか相違が見られた。いず れにせよ, 4 種の酵素之も Wermuth ${ }^{7)}$ の分類に従えば, アルドーケト還元酵素の中 のカルボニル還元酵素に属するものと考えられる。.また， 4 種の酵素とも薬物代謝 酵素として異物代謝ばかりでなく, $3 a(\beta)$ - や $17 \beta$-ヒドロキシステロイド酸化還元 酵素としてアンドロジェン代謝にも生体内で機能しているものと考えられる. 今後, 4 種の酵素間の一次構造の関係および他の研究室で精製されたアルドーケト還元酵 素との異同や構造面での関連性の有無には興味が持たれる。また，アルドーケト還 元酵素は大きなファミリーを形成していることが考えられていることから, シトク ローム P-450 の様に，一次構造に基ずく分類や命名法の確立が望まれる.

【ABSTRACT】 Four forms of naloxone reductase (NR1, NR2, NR3 and NR4) have been purified to homogeneous proteins on SDS-PAGE from the cytosolic fraction of rabbit liver. A11 the isozymes are monomeric proteins with molecular weights of $36,000-38,000$. NR3 and NR4 exhibited highly restricted cofactor specificity for NADPH and other two isozymes utilyzed NADPH as prefered cofactor over NADH. All the isozymes catalyzed stereospecific reduction of naloxone; NR1 formed 6a-naloxol and other three isozymes formed $6 \beta$-naloxol. In addition to naloxone, naloxone analogues which have a non-alkylated 3 -hydroxyl group such as naltrexone, dihydromorphinone and morphinone were efficiently reduced by NR2, NR3 and NR4 but were poor or inactive substrates for NR1. Other than naloxone analogues, a variety of carbony 1 compounds such as DL-glyceraldehyde, p-nitrobenzaldehyde, p-nitroacetophenone and phenanthrenequinone including oxosteroids were good substrates for all isozymes. Pyrazole and barbital had weak or no inhibitory effects on isozymes but quercetin acted as potent inhibitor. These findings indicate that the present enzymes satisfy most of the physicochemical and biochemical criteria expected as carbonyl reductase.

【REFERENCES】 1) S. H. Pol lock, Li fe Sci., 17, 465 (1975). 2) S. Roerig et a1., Drug Metab. Dispos., 4, 53 (1976). 3) S. Roerig et a1., Drug Metab. Dispos., $\frac{5}{0}, 454$ (1977). 4) R. L. Felsted et al., Biochem. Pharmacol., 29 , $1053(1980)$. 5) S. Yamano et al., J. Biol. Chem., 260, 5259 (1985). '6) S. Yamano et a1., Biochem. Pharmacol., 35, 4321 (1986). 7) B. Mermuth, in Enzymology of Carbony 1 Merabol ism 2 (T.G.Flynn and H. Weiner, eds.), p. 209, Alan R. Liss, New York (1985). 